\title{
Effect of Different Level of Nitrogen, Phosphorus and Potassium on Growth and Green Herb Yield of Origanum vulgare
}

\author{
Janaki Pal*, R.S. Adhikari and J.S. Negi \\ Department of Botany, Kumaon University, L.S.M. Govt. Post Graduate College \\ Pithoragarh, Uttrakhand, India \\ *Corresponding author
}

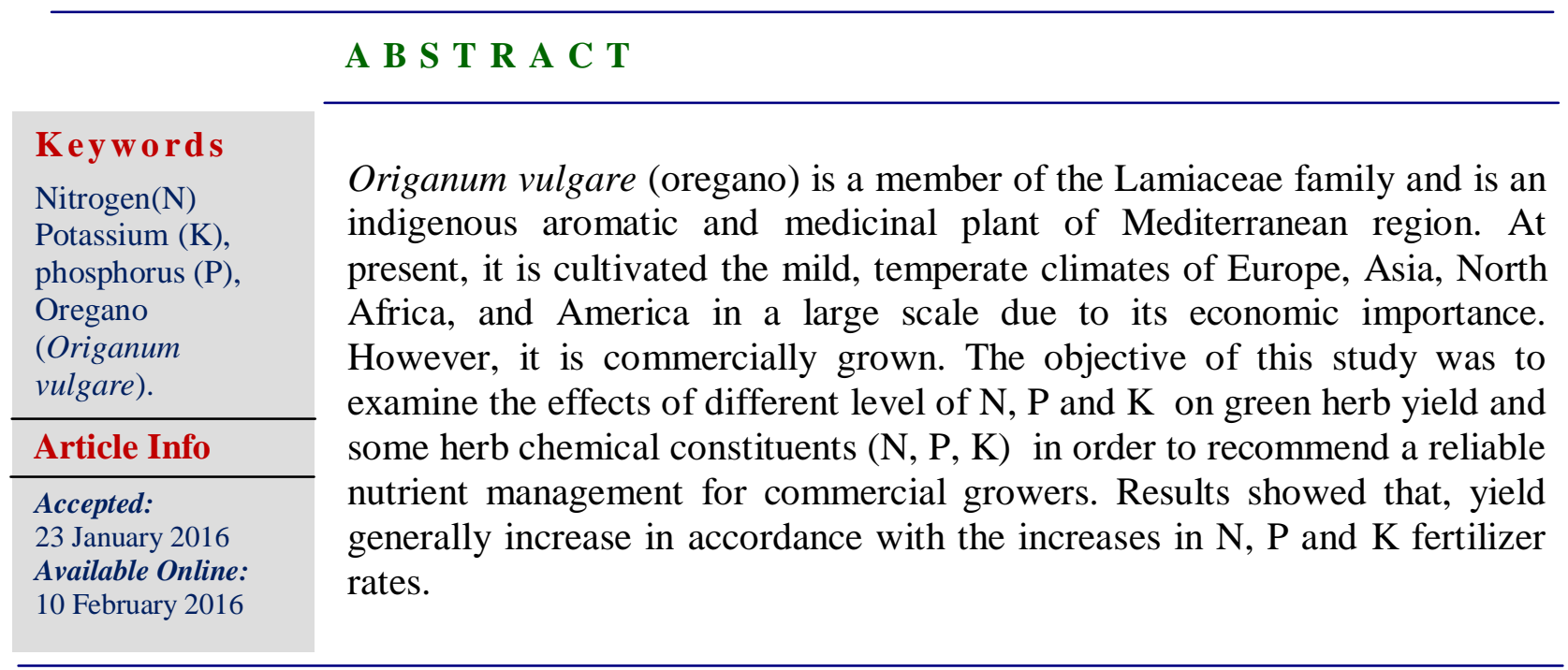

\section{Introduction}

Oregano (Origanum vulgare L.) belongs to the Lamiaceae family, which is indigenous to the Mediterranean region. It also is distributed and cultivated in many areas of the mild, temperate climates of Europe, Asia, North Africa, and America (Ietswaart, 1980; Goliaris et al., 2002). Oregano plays a primary role among culinary herbs in world trade. Traditionally, leaves and flowers of oregano are used in Lithuania mostly for their beneficial properties to cure cough and sore throats and relieve digestive complaints (Ien et al., 2008).
Oregano contains essential oils, rich in the two isomeric phenols carvacrol and thymol (Fleisher and Sneer, 1982; Kokkini and Vokou, 1989 and Vokou et al., 1993). The use of oregano as a medicinal plant is attributed to the biological properties of the herb and its essential oil composition. Findings report that oregano is antimicrobial (Didry et al., 1993; Chun et al., 2005 and Paster et al., 2005), an antioxidant (Capecka et al., 2005 and Jaloszynski et al., 2008), and probably stimulates the appetite (Ien et al., 2008). 
On the other hand, Karı et al. (2007) indicated that the secondary metabolites specific to the aromatic and medicinal plants are mainly controlled genetically but are strongly affected by environmental influences. Moreover, balanced nutrition of the thyme plant has not been examined thoroughly until recently. It is claimed that in order to achieve standard crops and standard quality oil yields, the commercial thyme growers need to practice well managed cultivated production systems (Bayram, 2003). In this regard, the significance of $\mathrm{N}$ fertilization is related (Ceylan, 1996) to visible emphasis of $\mathrm{N}$ on vegetative growth and to herbage area increase which directly increases the total oil yield. Baranauskiene et al. (2003) state the disadvantages of excess $\mathrm{N}$ fertilization which often results with high leaf NO3 concentrations. Palada et al. (1998) recommended 50 to $150 \mathrm{~kg}$ ha- $1 \mathrm{~N}$ for $O$. vulgare $\mathrm{L}$. as a concluding remark to his $\mathrm{N}$ fertilization testing. The same author also reports the beneficial effects of cow manure and urea as $\mathrm{N}$ sources (Palada et al., 1995) which are generally practiced in two splits; in spring and after the first harvest. However, not much information is found on the efficient use of $\mathrm{P}$ and $\mathrm{K}$ fertilizers. Some growers apply $\mathrm{P}$ and $\mathrm{K}$ during the soil preparation in spring in the form of compound fertilizers. Ateia et al. (2009) claimed that the mixture of compost + sheep manure applied at 3:1 ratio give high essential oil yields. The content of essential oils and their composition are affected by different factors, including genetic makeup (Muzik et al., 1989) and cultivation conditions, such climate, habitat, harvesting time, water stress, and the use of fertilizer (Min et al., 2005; and Stute, 2006).

The improvement of plant nutrition can contribute to increased resistance and production when the crop is submitted to water stress. Plant nutrition is one of the most important factors that increase plant production. Nitrogen is most recognized in plants for its presence in the structure of the protein molecule. In addition, nitrogen is found in such important molecules as purines, pyrimidines, porphyrines, and coenzymes. Purines and pyrimidines are found in the nucleic acids RNA and DNA, which are essential for protein synthesis. The porphyrin structure is found in such metabolically important compounds as the chlorophyll pigments and the cytochromes, which are essential in photosynthesis and respiration. Coenzymes are essential to the function of many enzymes. Accordingly, nitrogen plays an important role in synthesis of the plant constituents through the action of different enzymes. Nitrogen limiting conditions increase volatile oil production in annual herbal. Nitrogen fertilization has been reported to reduce volatile oil content in Juniperus horizontalis (creeping juniper) (Fretz, 1976), although it has been reported to increase total oil yield in oregano (Origanum vulgare) (Baranauskienne et al., 2003). However, studies on agronomic factors such as application of potassium humate and irrigation intervals as well as nitrogen fertilization on yield and essential oils of oregano have not been investigated thoroughly until now.

The objective of this study was to recommend a reliable nutrient management for commercial wild thyme growers by examining the effects of different rates of $\mathrm{N}, \mathrm{P}$ and $\mathrm{K}$ fertilizations on green herb yield (leaf + stalk + flower) and some herb nutrients $(\mathrm{N}, \mathrm{P}, \mathrm{K})$.

\section{Materials and Methods}

Seed or one-month-old seedling or small size plant will be selected for cultivation. The net plot size will be kept at $1.35^{*} 1.00 \mathrm{~m}$. 
twenty seven treatment combinations of fertilizers would be consisted with three levels nitrogen $(0,75,150 \mathrm{~kg}$./ha. $)$. Three levels of phosphorus $(0,125,250 \mathrm{~kg}$./ha. $)$ and three level of potassium $(0,75,150 \mathrm{~kg}$./ha. $)$. Nitrogen will be supplied by urea, single super phosphate and murate of potash respectively. The hole quantity of phosphorus half of potash and nitrogen was applied at the time of planting the rest half dose of nitrogen and potash was given one month after planting. Seedling were planted in well prepared flat beds by spacing $20 * 15$ $\mathrm{cm}$. or according to plant size as suggested by pal and phogat 1984 . The observation on plant growth, yield per hectare, leaf area index, rhizome yield will be recorded. Profit would be examined and production will be popularized among local youth.

Experiment plot would be selected on botanical garden L.S.M.P.G.College Pithoragarh, Uttrakhand, India.

\section{Results and Discussion}

Green herb yields were found generally higher in the second year of the experiment in all of the treatments. Each year, yield response to the enhanced, $\mathrm{K}$ and $\mathrm{P}$ fertilizations were found positive and statistically significant at $1 \%$ level. The interaction effect of $\mathrm{N}, \mathrm{P}$ and $\mathrm{K}$ fertilizations on yield was not found significant in the first year where as was determined significant in the second year (Table 2). In this context, the highest yield was obtained in the highest rate of $\mathrm{N}(150 \mathrm{Kg}$ urea /ha.) $\mathrm{P}(125 \mathrm{~kg}$ phosphorus/ha.) and $\mathrm{K}(150 \mathrm{~kg}$ potash/ha.) fertilizations. Nutrient elements $(\mathrm{N}, \mathrm{P}$ and $\mathrm{K})$ of the green herb were also analyzed in both of the study years. Results of the statistical analyses showed that the herb N, P and $\mathrm{K}$ contents were significantly higher. On the other hand, in the first and second years of this study, statistically significant interaction effects of $\mathrm{N}, \mathrm{P}$ and $\mathrm{K}$ fertilizations were determined on the $\mathrm{N}, \mathrm{P}$ and $\mathrm{k}$ contents of the herb respectively.

The data of this study showed that N ,P and $\mathrm{K}$ fertilizations positively affect the developments in Origanum vulgare, its yield as well as its quality as a medicinal and herbaceous plant. Among many plant growth factors, the nutritional requirements of the crops are considered to be the most important factor. Generally the growth, development, yield and the quality of herbs are affected by genetic background; however, environment and the cultural practices are as well important (Karık, et al., 2007). It is well known that $P$ is an essential element in reproductive and vegetative growth and flower number can increase by the increased $\mathrm{P}$ applications (Mengel and Kirkby, 2001). Phosphorus also has many other cellular functions in plants and affects the primary and secondary metabolites. Therefore, $\mathrm{P}$ fertilization in medicinal herbs is strongly recommended especially in cites with low available soil P (Marschner, 1995).

Table.1 Soil Properties of Experimental Site

\begin{tabular}{|c|c|c|c|c|c|c|c|c|c|}
\hline \multirow[t]{2}{*}{ Site } & \multirow{2}{*}{$\begin{array}{l}\text { Colour } \\
\text { (dry) }\end{array}$} & \multirow[t]{2}{*}{ elevation } & \multirow{2}{*}{$\begin{array}{l}\text { Soil } \\
\text { text }\end{array}$} & \multicolumn{3}{|c|}{ Particle-size distribution(\%) } & \multirow{2}{*}{$\begin{array}{l}\mathrm{Ph} \\
(1: 2.5)\end{array}$} & \multirow{2}{*}{$\begin{array}{l}\text { Org } \\
\text { carbon } \\
\mathrm{Kg}_{-}{ }^{1}\end{array}$} & \multirow{2}{*}{$\begin{array}{l}\mathrm{Cec} \\
\mathrm{Cmo} \\
(\mathrm{p}+) \\
\mathrm{Kg}_{-}{ }^{1}\end{array}$} \\
\hline & & & & $\begin{array}{l}\text { Sand } \\
(2.0-0.05 \\
\mathrm{mm})\end{array}$ & $\begin{array}{l}\text { silt }(0.05- \\
0.002 \mathrm{~mm})\end{array}$ & $\begin{array}{l}\text { Clay } \\
(<0.002 \\
\mathrm{mm})\end{array}$ & & & \\
\hline $\begin{array}{l}\text { L.S.M.G.P.G.C. } \\
\text { Pithoragarh }\end{array}$ & $\begin{array}{l}\text { Olive } \\
\text { yellow }\end{array}$ & 1498 & silt & 7.6 & 68.9 & 23.5 & 5.9 & 14.7 & 9.3 \\
\hline
\end{tabular}


Table.2 Effect of N, K and P Fertilization on Green Herb Yield (kg/ha.) for 2011 and 2012 Seasons

\begin{tabular}{|l|l|l|}
\hline Combination no. & First season (2011) & Second season $(2012)$ \\
\hline $\mathrm{C} 1$ & 15500 & 16800 \\
\hline $\mathrm{C} 2$ & 16000 & 17400 \\
\hline $\mathrm{C} 3$ & 16500 & 18600 \\
\hline $\mathrm{C} 4$ & 17000 & 19800 \\
\hline Mean & 16250 & 18150 \\
\hline
\end{tabular} $\begin{aligned} & \mathrm{C} 1=\text { control,C2=N(150 kg/ha.)+P(250 kg/ha. })+\mathrm{K}(75 \mathrm{~kg} / \mathrm{ha}), \mathrm{C} 3=\mathrm{N}(75 \mathrm{~kg} / \mathrm{ha} .)+\mathrm{P}(0 \mathrm{~kg} / \mathrm{ha} .)+\mathrm{K}(75 \mathrm{~kg} / \mathrm{ha} .) \quad \text { and } \mathrm{C} 4=\mathrm{N}(150 \\
& \mathrm{kg} / \mathrm{ha} .)+\mathrm{P}(125 \mathrm{~kg} / \mathrm{ha} .)+\mathrm{K}(150 \mathrm{~kg} / \mathrm{ha} .)\end{aligned}$

Table.3 Effect of N, P And K Fertilization on N, P and K Conent (\%) For2011 and 2012 Seasons

\begin{tabular}{|l|l|l|l|l|l|l|}
\hline \multicolumn{9}{|c|}{$\%$} & \multicolumn{2}{|c|}{ P } \\
\hline & \multicolumn{2}{|c|}{$\mathrm{N}$} & \multicolumn{2}{c|}{ K } \\
\hline & $\begin{array}{l}\text { First season } \\
(2011)\end{array}$ & $\begin{array}{l}\text { Second } \\
\text { season (2012) }\end{array}$ & $\begin{array}{l}\text { First season } \\
(2011)\end{array}$ & $\begin{array}{l}\text { Second } \\
\text { season (2012) }\end{array}$ & $\begin{array}{l}\text { First season } \\
(2011)\end{array}$ & $\begin{array}{l}\text { Second season } \\
(2012)\end{array}$ \\
\hline C1 & 1.825 & 1.825 & 0.252 & 0.252 & 1.072 & 1.072 \\
\hline C2 & 1.828 & 1.830 & 0.258 & 0.268 & 1.140 & 1.165 \\
\hline C3 & 1.830 & 1.832 & 0.252 & 0.252 & 1.180 & 1.190 \\
\hline C4 & 1.833 & 1.837 & 0.262 & 0.272 & 1.200 & 1.225 \\
\hline Mean & 1.829 & 1.831 & 0.256 & 0.261 & 1.148 & 1.163 \\
\hline
\end{tabular}

$\mathrm{C} 1=$ control, $\mathrm{C} 2=\mathrm{N}(150 \quad \mathrm{~kg} / \mathrm{ha})+.\mathrm{P}(250 \quad \mathrm{~kg} / \mathrm{ha})+.\mathrm{K}(75 \quad \mathrm{~kg} / \mathrm{ha}), \mathrm{C} 3=\mathrm{N}(75 \quad \mathrm{~kg} / \mathrm{ha})+.\mathrm{P}(0 \quad \mathrm{~kg} / \mathrm{ha})+.\mathrm{K}(75 \quad \mathrm{~kg} / \mathrm{ha}$.$) \quad and \quad \mathrm{C} 4=\mathrm{N}(150$ $\mathrm{kg} / \mathrm{ha}.)+\mathrm{P}(125 \mathrm{~kg} / \mathrm{ha})+.\mathrm{K}(150 \mathrm{~kg} / \mathrm{ha}$.

Similarly, it is also very well known that $\mathrm{K}$ fertilizers improve growth parameters and yield quality (Mengel and Kirkby, 2001). Potassium fertilizers proved its role in plant metabolism, carbohydrate synthesis, water transport in xylem, cell elongation. Singh (2001) reported that addition of $\mathrm{K}$ resulted with higher herb yields.

In this current study, green herb yield, some of the herb nutrient elements like $\mathrm{N}, \mathrm{P}, \mathrm{K}$ positively responded toN, $\mathrm{P}$ and $\mathrm{K}$ fertilizer treatments. The highest herbal yield was determined in $150 \mathrm{~kg}$ urea/ ha.+1 $25 \mathrm{~kg}$ phosphorus/ ha. $+150 \mathrm{~kg}$ potash/ha. treatment in both of the study seasons. It is worth reporting that this specified highest yield obtained from the $150 \mathrm{~kg}$ urea/ ha.+ $125 \mathrm{~kg}$ phosphorus/ ha. +150kg potash $/ \mathrm{ha}$.

The present study can be concluded that if the herb yield evaluated and weighed and ranked according to the treatments, we can reach the conclusion that if economically viable $150 \mathrm{~kg}$ urea, $125 \mathrm{~kg}$ phosphorus and $150 \mathrm{~kg}$ Potash per hectare could be recommended for about $19800 \mathrm{~kg}$ of green herb yield ha- 1 . In case $\mathrm{N}$ fertilization is necessary according to soil testing, recommendations should be followed.

\section{Acknowledgment}

The author is grateful to Dr. R. S. Adhikari, the head of department of Botany, L.S.M.G.P.G.C. Pithoragarh for providing all kinds of facilities during this study.

\section{References}

Chun, S. Vattem, D.A. and Shetty, K. 2005. Phenolic antioxidants from clonal oregano (Oreganum vulgare) with antimicrobial activity against Helicobacter pylori. Process Biochemistry, 40 (2), 809-816.

Delfine S.,Loreto F., Pinell P., Tognetti R., and 
Alvino A.,2005.Isoprenoids content and photosynthetic limitations in rosemary and spearmint plants under water stress. Agriculture Ecosystems and Environment, 106: 243-252.

Kala CP (1998). Ethnobotanical Survey and Propagation of Rare Medicinal Herbs in the Buffer Zone of the Valley of Flowers National Park Garhwal Himalaya. International Centre for Integrated Mountain Development, Kathmandu, Nepal.

Palada MC, Crossman SMA, Kowalski JA (1995). Growth and yield response of thyme (Thymus vulgaris L.) to sources of nitrogen fertilizer. In Proceedings of the Caribbean Food Crops Society.

Nautiyal MC, Viany Prakash, Nautiyal BP (2002). Cultivation techniques of some high altitude medicinal herbs. Ann. For. 10: 6267.

Fleisher, A. and Sneer, N. 1982. Oregano species and Origanum chemotypes. J. Sci. Food Agric., 33: 441-446.

Fortun, C. Fortun, A. and Almendros, G. 1989. The effect of organic materials and their humified fractions on the formation and stabilization of soil aggergates. The Science of the Total Environment, 81/82: 561-568.

Fretz, T.A. 1976. Effect of photoperiod and nitrogen on the composition of Juniperus horizontalis Moench.cv plmosa. J. Am. Soc. Hortic. Sci., 101:611-613.

Goliaris, A.H. Chatzopoulou, P.S. and Katsiotis, S.T. 2002. Production of new Greek oregano clones and analysis of their essential oil.J. herbs, Spices \& medicinal plants, vol. 10(1): 29-35.

Guenther, G. 1961.The essential oils VIII. Robert E.D. Nastrand Comp. Inc. Toronto, NewYork, London.

Nautiyal, M. C. and Nautiyal, B. P., In Agrotechniques for High Altitude Medicinal and Aromatic Plants, Bishan Singh,
Mahendra Pal Singh, Dehdradun, 2004.

Kala CP, Dhyani PP, Sajwan BS (2006). Developing the medicinal plants sector in northern India: Challenges and opportunities. J.Ethnobiol. Ethnomed. 2: 32.

Nautiyal, M. C., Cultivation of medicinal plants and biosphere reserve management in alpine zone. In Conservation and Management of Biological Resources in Himalaya (Eds Ramakrishna, P. S. et al.), GBPIHED and Oxford \& IBH, New Delhi, 1994, pp. 570582.

Dhar, U., Conservation implication of plant endemism in high altitude Himalaya. Curr. Sci., 2002, 82, 141-148.

Alam Ghayur, Lucian Peppelenbos, "Cultivation of Medicinal Plants in Uttarakhand", Economic and Political Weekly, March 7, 2009

Ien, J.R. Ivanauskas, L. Janulis, V. and Tas, V.J. 2008. Composition and variability of phenolic compounds in Oroganum vulgare from Lithuania. Biologija,Vol. 54. Nr. 1. P. 45-49.

Ietswaart, J.H. 1980. A taxonomic revision of the genus origanum (labiatae). Leiden university Press. The Hague.

Jackson, M.L. 1973. Soil Chemical Analysis. Published by prentice Hall Indian Private Ltd., M.97, Connght Citrus, New Delhi-1, India.

Jaloszynski, K. Figiel, A. and Wojdylo, A. 2008. Drying kinetics and antioxidant activity of oregano. Acta Agrophysica, 11 (1), 81-90.

Shivkumar V, Anandlakshmi R, Warrier RR, Tigabu M, Oden PC, Vijayachandran SN, Geetha S, Singh BG (2006). Effect of presowing treatments, desiccation and storage conditions on germination of Strychnos nux-vomica seeds, a valuable medicinal plant. New Forest32:121-131.

\section{How to cite this article:}

Janaki Pal, R.S. Adhikari and Negi, J.S. 2016. Effect of Different Level of Nitrogen, Phosphorus and Potassium on Growth and Green Herb Yield of Origanum vulgare. Int.J.Curr.Microbiol.App.Sci.5(2): 425-429. doi: http://dx.doi.org/10.20546/ijcmas.2016.502.047 